\title{
Denis Diderot on War and Peace: Nature and Morality
}

\section{Guerra y paz en Denis Diderot: naturaleza y moralidad}

\author{
Whitney Mannies ${ }^{1}$ and John Christian Laursen ${ }^{2}$ \\ University of California (United States)
}

Recibido: 15-05-14

Aprobado: 19-06-14

\begin{abstract}
Denis Diderot's ideas about war and peace crystalize many of the contradictions in the world that he identified. On the one hand, war is a natural product of contradictions between natural law and human developments. On the other hand, it can and should always be subject to moral judgment based on a wide-ranging knowledge of history and context. War can be good if it eliminates

\footnotetext{
${ }^{1}$ (wmann001@ucr.edu). Profesora del Department of Political Science (University of California, Riverside). Entre sus publicaciones más recientes cabe destacar: "Skepticism and Politics in the Seventeenth and Eighteenth Centuries," Rivista di Storia di Filosofia, 68, 2013, pp. 601-604. A critical summary of the proceedings of the conference "Skepticism and Politics in the Seventeenth and Eighteenth Centuries" held at the William Andrews Clark Memorial Library, UCLA, May 2012; "Marie Dupré," in Mary Hays, Female Biography; or, Memoirs of Illustrious and Celebrated Women, of All Ages and Countries (1803). Chawton House Library Series: Women's Memoirs, ed. Gina Luria Walker, Memoirs of Women Writers Part III (London: Pickering \& Chatto: 2014). (Notes for an entry in a new edition of a classic work in women's biography).

${ }^{2}$ (john.laursen@ucr.edu) Profesor del Department of Political Science (University of California, Riverside). Algunas de sus publicaciones son: "Pierre Bayle's The Condition of Wholly Catholic France", en History of European Ideas 40: 312-324. Co-authored with Charlotte Stanley, 2014; "Michael Oakeshott, Wendy Brown, and the Paradoxes of Anti-Moralism", en Ágora-Papeles de Filosofia 32, 2013, 67-80; "Enfield's Brucker and Christian Anti-scepticism in Enlightenment Historiography of Philosophy" in S. Charles and P. Smith, eds., Scepticism in the Eighteenth Century: Enlightenment, Lumières, Aufklärung (Dordrecht: Springer, 2013), 155-169 (2013); Paradoxes of Religious Toleration in Early Modern Political Thought (Lanham: Lexington Books, 2012). Co-edited with María José Villaverde. Editors' contribution: "Introduction", 1-8; JCL's contributions: "Spinoza on Lying for Toleration and His Intolerance of Atheists", 39-52 and "Intolerance of Fanatics in Bayle, Hume, and Kant", 177-192 (2012); "Hamburg/Altona as a Fertile Ground for Theories About Freedom of the Press in the Mid-Eighteenth Century" in A. Steiger and S. Richter, eds., Hamburg: Eine Metropolregion zwischen Früher Neuzeit und Aufklärung (Berlin: Akademie Verlag, 2012), 315-327.
} 
tyranny, and bad if it limits freedom, equality, and prosperity. Peace can be good if it cultivates the latter, and bad if it freezes inequality. Diderot never allows himself to rest on universal judgments for all times and all places, but insists upon never-ending comparisons and contrasts between the moral world and the natural world. Philosophical materialism provides the basis for his understanding of the world, but morals provide the instruments of judgment.

Key-words: Denis Diderot, war, peace, nature, materialism, morality, colonialism.

\section{Resumen}

Las ideas de Denis Diderot sobre la guerra y la paz revelan muchos de las contradiciones que el identificó en el mundo. Por un lado, la guerra es un producto natural de contradiciones entre la ley de la natura y las instituciones humanas. Por otro lado, siempre debe ser sometido a juicio moral basado en conocimiento amplia de la historia y contexto. La guerra puede ser buena si derota a la tiranía, y mala si limita a la libertad e igualdad. La paz puede ser buena si aumenta a la libertad, la igualdad, y la prosperidad, y mala si mantiene la desigualdad. Diderot nunca se permite juicios universales por todos los tiempos y todos los sitios, pero insista en comparaciones y contrastes sin fin entre el mundo moral y el mundo natural. El materialismo filosófico es el fundamento de su manera de entender el mundo, pero los aspectos morales son sus instrumentos de juicio.

Palabras-clave: Denis Diderot, la guerra, la paz, la naturaleza, el materialismo, la moralidad, el colonialismo.

What did Diderot say about war and peace? When and how did he justify war? Did he promote revolution, or did he prefer reform? Assessments of Diderot's thought on war and peace range broadly. On one end of the spectrum, he is considered "reform-minded" and an advocate of organic social change ${ }^{3}$. On the other end, he is held to be "the first effective advocate in the modern world of social and political reconstruction through violent revolution"4.Some argue that Diderot moderated his views on war over time, distancing himself from the Lockean right to revolution that he endorsed in his Encyclopedia articles "Autorité politique" (1751; errata added 1754) and "Droit naturel" (1755). Others portray his thought as increasingly radical, culminating in the advocacy

\footnotetext{
${ }^{3}$ Dennis C. Rasmussen, "Burning Laws and Strangling Kings? Voltaire and Diderot on the Perils of Rationalism in Politics", The Review of Politics, 73 (2003), pp. 77-104.

${ }^{4}$ Anthony Strugnell, Diderot's Politics: A Study of the Evolution of Diderot's Political Thought After the Encyclopedie, The Hague, Martinus Nijhoff, 1973.

5 Rasmussen 2003.
} 
of a general right to insurrection and the necessity of violent revolution in both Europe and the colonies ${ }^{6}$.

It is our intention to piece together the story Diderot told in Observations on the Nakaz (1767), ${ }^{7}$ in the excerpts he contributed to Raynal's Philosophical and Political History of the Two Indies (1770-1783) ${ }^{8}$, in his Supplément to the Voyage of Bougainville $(1773)^{9}$, and other places - about the descent into war. We argue that Diderot views nature as vast and dynamic: its motions, for all their regularity, lie nevertheless largely beyond the scope of our perception. Nature therefore declines to delineate clear and robust positive prescriptions, and it is dynamic enough to encompass a broad (yet still limited) range of behaviors. Thus Diderot posits a sparse and abstract theory of natural law that avoids both cultural relativism and the positive prescriptions that would attend a more robust natural law. Given a broad range of possible moral behaviors, Diderot argues, humans ought to consider their particular geographical and social circumstances and use reason to forge positive laws that aim at the common good, modifying the laws as necessary. Through the ongoing modification of laws to accord with nature and circumstances, peace is maintained. However, as positive laws become beholden to particular interests, their connection to the common good and accordance with nature become increasingly distorted. Finally, their contradictions become unbearable. War is the result.

Set against the background of his theory of human nature as a set of dynamic and highly varied behaviors, it is remarkable how many of the interventions that Diderot makes in the History of the Two Indies are moral judgments. Moral evaluations help explain and justify society's descent into revolution, why colonialism is particularly evil but also why, at least in the European context, war may be inadvisable. As we will show, Diderot argues

${ }^{6}$ Yves Benot, De l'atheisme a l'anticolonisme, Paris, Librairie François Maspero, 1981, pp. $22,154$.

Denis Diderot, Observations sur le Nakaz, [in Paul Vernière, ed.: EEuvres politiques, Paris, Éditions Garnier Frères, 1963]; Denis Diderot, Political Writings, John Hope Mason and Robert Wokler, eds., Cambridge, Cambridge University Press, 1992 [hereafter cited in parentheses in the text as "ON" followed by the page number in Vernière, the section number, and the page number in Mason and Wokler]. In Spanish, see Denis Diderot, Escritos politicos, Antonio Hermosa Andújar, ed., Madrid, Centro de Estudios Constitucionales, 1989.

8 Guillaume-Thomas Raynal [and Denis Diderot], Histoire philosophique et politique des Établissemens et du commerce des Européens dans les Deux Indes, Neuchâtel, Libraires Associés, 1783; hereafter abbreviated HDI; Denis Diderot, Extracts from the Histoire des Deux Indes [in John Hope Mason and Robert Wokler, eds.: Cambridge, Cambridge University Press, 1992] [hereafter cited in parentheses in the text as "HDI" followed by book and page number of the French edition and the page number in Mason and Wokler, if available]

${ }^{9}$ Denis Diderot, Supplément au voyage de Bougainville [in H. Dieckmann, J. Proust, and J. Varloot, eds. Oeuvres complètes, Paris, Hermann, 1975-2004] hereafter abbreviated DPV; Denis Diderot, "The Supplément au Voyage de Bougainville [in John Hope Mason and Robert Wokler, eds.: Cambridge, Cambridge University Press, 1992] [hereafter cited in parentheses in the text as "SVB" followed by the page number in DPV and the page number in Mason and Wokler]. 
that revolutions are more likely to be undertaken for the wrong reason (power) than for the right one (liberty). In what follows we will explore the role of Diderot's moral philosophy in his theory of war and peace.

Though we pay most attention to Diderot's later and most explicitly political texts - the Supplément au Voyage de Bougainville, his additions to Raynal's Histoire des deux Indes, the Observations sur le Nakaz-this by no means implies the irrelevance of his earlier Encyclopedia articles or even his scientific, dramatic, or aesthetic works. In fact, we aim to demonstrate that Diderot's views on war are, like so many other aspects of his thought, extensions of his view of nature ${ }^{10}$. By concentrating on Diderot's explicit statements on war found mostly in certain later texts, we do not mean to imply that earlier or ostensibly apolitical texts are irrelevant to his political thought. In fact, couching his thought on war in the framework of his broader philosophy of nature reveals its most distinctive aspects.

\section{From natural law to positive law}

In Diderot's view, society descends into war after natural rights have been repeatedly and systematically violated. What did he mean by "natural rights"? In the article "Droit naturel", he notes that everyone seems to have a different idea of which rights appear most glaringly self-evident. To clarify this debate, he endeavors to filter out all but the most self-evident of the self-evident by way of critical examination. (Of course, this is merely doing what all natural law theorists claim to do-an obvious objection apparently lost on him). By rejecting a divine origin and emphasizing the primacy of the situation-specific common good, Diderot does manage to arrive at a comparatively attenuated natural law ${ }^{11}$. He argues that our reason, working in accordance with our natural sociability, can enlighten us as to the best way to interpret abstract natural law to fulfill the volonté générale, in effect arguing from the common good back to natural law instead of the other way around. In this article and elsewhere, he refrains from fleshing out the content of what he considers natural law, preferring instead that it remain abstract and thus amenable to a variety of interpretations and behaviors. He even criticizes Beccaria, who would seem like a natural ally, for basing his penal reforms on inflexible natural laws instead of the common

10 Several recent studies of Diderot have undertaken to demonstrate how many topics in his famously vast and protean œuvre are not as disconnected as they are often characterized, but are rather unified by an underlying conception of nature that illuminates his positions on issues ostensibly far removed from nature: his art criticism, his drama, his economic theory, and, as we argue, his position on war. See Colas Duflo, Diderot philosophe, Paris, Honoré Champion, 2003.

${ }^{11}$ Sankar Muthu makes a similar argument about Diderot's moral thought in the colonial context. See Sankar Muthu, Enlightenment Against Empire, Princeton, Princeton University Press, 2003. 
good $^{12}$. The common good is the thing to aim at, and there are a few abstract values that will always accord with it. These could be called natural laws. It is sufficient, however, to simply appeal to the common good without employing the language of natural law, since an appeal to natural law has a tendency to ossify our ideas.

What substance he did clarify, however, emphasized basic individual liberties such as freedom of conscience, expression, the press, and religion ${ }^{13}$. Securing these civil rights was arguably the fundamental political goal of the Encyclopédie $e^{14}$. Sexual freedom was also an important natural right for Diderot. Never an apologist for monogamy, he held most constraints on sex to be distortions of human nature, contrary to both individual and social $\operatorname{good}^{15}$. In addition, Diderot was committed to property rights; they are, after all, crucial for the expression of individual liberties ${ }^{16}$. In one of his frequent recommendations for securing the right to property in the Obervations sur le Nakaz (LX; DPV; 118), he argues that laws will not contradict, no matter how numerous, if they all aim at the fixed points of liberty and property. Such rights, appropriately tailored to a people's circumstances, will always tend towards the common good.

What is the relationship between natural law and positive law? After all, nature contains sentiments of sociability and enmity, thus positive laws cannot be the essential consequences of natural law (ON, 372; XXX; 102). Diderot points out that even sociable sentiments turn to vices when taken in isolation, as when compassion for a criminal trumps justice (HDI, 19:291-294; 212), and he frequently criticizes the physiocratic claim to derive positive law directly from natural law (e.g. ON, 365-366; XIX; 96-97). Yet even though positive law does not necessarily follow natural law, it can and should accord with it. This accordance results when reasonable people reflect on the scope of behaviors contained in the natural law and consider which behaviors would best harmonize with the common good in the context of their particular society. Through a dialogic synthesis with nature and our empirical reality, we arrive at

12 Benot 1981, p. 141. Diderot criticizes the use of capital punishment in the Observations (ON 373-5; XXXV; 103-104). However, unlike Beccaria, Diderot's concern with social utility keeps him from totally rejecting it. See (ON 343-344; I; 81) and (ON 395-396; LXII; 119).

${ }_{13}$ In one contribution to the History of the Two Indies (HDI 10:120-122; 183) Diderot spells out several arguments in support of freedom of expression: to limit expression only demonstrates the sovereign's inclination to tyranny; when men of genius are silenced, the nation is less able to discern its true interest; authors are invigorated by rebellious sentiment; it makes the sovereign, who has an entire army, look weak if he is afraid of a few writings. Inevitably there will emerge stupid ideas, but he asks, "Is it better for a people to be eternally deadened than sometimes troublesome?"

14 A.M. Wilson, "The development and scope of Diderot's political thought", Studies on Voltaire and the Eighteenth Century, 27 (1963), pp. 1871-1900.

15 See Orou's speech and the discussion of the Miss Polly Baker episode in section three of SVB (599-616; 47-58).

${ }^{16}$ See for example ON (379-380; XLIV; 107), (367-368; XXI; 98), (381-382; XLVI; 108-109), and (396; LXIII; 119); HDI (9:37-38). 
a code of civil and religious law that accords with nature, but which nature in and of itself cannot prescribe ${ }^{17}$.

The distinction between necessarily following and according with is an important one because it is the basis of Diderot's self-differentiation from Rousseau. Though Diderot sometimes appears to be acquiescing in a Rousseauan idealization of nature ("Nature made all the good laws; it is the legislator who makes them public" (ON, 371; XXVII; 101)), he is in fact consciously opposing such idealism. Indeed, some of Diderot's clarifications demonstrate that he realizes that his audience is liable to conflate their positions ${ }^{18}$. Consider this exchange in his Supplement to the Voyage of Bougainville $(630 ; 67)$, in which A draws the incorrect (Rousseauan) conclusion from B's observation that men are subject to a natural code, a civil code, and a religious code:

A: ...the last two should be strictly patterned on the first, which we carry with us engraved in our hearts, and which is always the strongest.

B: That's not quite right. We have no more in common with other human beings at birth than an organic similarity of form, the same need, and attraction to the same pleasures and a shared aversion to the same pains. These are the things which make man what he is, and which should form the basis of the morality suited to him.

How is B's position different from A's? If natural pleasures and aversions are the basis of our morality, is this not the same as morality being "strictly patterned on" the natural code? Yet we are told, "That's not quite right". Though the natural code limits the scope of all possible reasonable moral behavior, reasonable people must then reflect on precisely which elements of the natural code are conducive to the common good, taking into account the concrete situation of a particular society. While there are a variety of moral ways a society might approach sex that could accord with natural law, for example, a society comprised of only one gender (HDI, 9:274-277), or a society which severely punishes only women for adultery (SVB, 599-616; 47-58) would fall outside the scope of our nature.

In addition to emphasizing the variety of positive laws that may potentially follow from nature, Diderot emphasizes the necessity for frequently reevaluating positive laws. Clinging too tightly to existing laws or legal commentaries blinds us to the adjustments necessary for maintaining the common good in a dynamic society. Diderot rarely admires tradition, usually portraying it as a blinding force with no role to play in our political thought. Dynamic societies

\footnotetext{
17 See Dena Goodman, "The Structure of Political Argument in Diderot's Supplément au Voyage de Bougainville”, Diderot Studies, 21 (1983), pp. 123-137.

${ }^{18}$ See HDI 6:257-259: “Ce n'est pas toutfois que je préférasse l'état sauvage à l'état civilisé. C'est une protestation que j'ai déjà faite plus d'une fois".
} 
require "good magistrates" who, though elite, are constantly re-evaluating the public good in light of reason and nature ${ }^{19}$. Hence laws may be both perpetually fixed towards the ends of liberty and property (ON, 379-380; XLIV; 107) and frequently changed.

It is interesting that Diderot rejects both tradition and overarching, rational political projects. This is a surprising contrast to the Enlightenment's scientific outlook, which is often characterized as logically resulting in the rejection of the former and the embrace of the latter. Diderot's scientific outlook, however, is grounded in a view of nature as dynamic, enormous, and infinitely complex. Consequently, perception is inevitably partial. Reason ought to be continually applied anew and conclusions ought not be so conclusive ${ }^{20}$. Thus reason trumps tradition and systematization: both calcify our thoughts, behaviors, and institutions so that, failing to adapt to an evolving society, they become antiquated and incongruous. This incongruity presages war.

\section{The descent into war}

Reasonable legislators will not always wisely determine contextuallyappropriate positive laws that accord with nature. Over time, social hierarchies develop, and different factions - such as the aristocracy, the monarchy, or priestsbegin to make laws and customs with a view towards their own particular interests, without regard for either the common good or the limits of nature. They may enslave, coercively colonize, or denounce perfectly innocent sexual behavior. A sovereign may forget to associate his own good with the good of his nation- "He thinks he is at war with it"-and thereby condemns his people to hunger (ON, 379-380; XLIV; 107). Religion and "l'esprit de conquêtes" detach Europeans from concern for the wellbeing of all (HDI, 6:137-139). As these self-interested laws proliferate, they become increasingly contradictory - not only contradicting nature and the common good, but contradicting other laws. When a nation's laws are at odds with its geography and social situation, a nation is bound to be disorderly (9:233). And everything against nature is fated to end (13:113). Unsustainable contradictions cause more and more human suffering (18:273-279; 200). Finally, this fraught situation reaches a fever pitch and the "fermentation violente" explodes. Society buckles under these strained layers of contradiction and descends into a state of war.

${ }^{19} \mathrm{ON}, 387$; LII; 113. Diderot distrusted the masses as repositories of political wisdom and was more inclined to trust elite legislators and magistrates because he thought these elites could be more flexible in their reasoning, not, as Geoffrey Bremner argues, because they could more effectively weave a monolithic façade of order. Geoffrey Bremner, Order and Chance: The Pattern of Diderot's Thought, Cambridge, Cambridge University Press, 1983. See also ON (377-378; XL; 106) and (389; LIV; 114).

20 Diderot's fiction, too, was written in such a way as to bring about the continually renewed application of reason. See Whitney Mannies, “The Style of Materialist Skepticism: Diderot's Jacques le fataliste", Philosophy and Literature, forthcoming. 
In this way, Diderot's vision of the breaking point of revolution is animated by his vision of nature. It would be wrong to presuppose, however, that his was a monolithic nature, progressing along predictable mechanical laws or following inexorably through determined stages of historical progression: this is the nature of Helvétius, de Quesnay, or La Mettrie. Diderot's view, on the other hand, is in the vein of Lucretius and Epicurus: nature is so vast and dynamic and our own ability to perceive its connections is so limited that the idea of predicting and controlling nature is no more than vain pretense. Diderot's materialism resulted in skepticism regarding inflexible and grand social and political systems which resist being modified to accommodate nature's dynamism or our changing and increasing knowledge of nature. ${ }^{21}$ Older societies have accrued layer upon layer of inflexible institutions, all more interested in perpetuating themselves than in adjusting to differences in nature and the common good. Eventually, these inflexible institutions become so contradictory and contrary to the public good that reasonable behavior is impossible. The laws of nature are violated by civil laws (HDI 17:27). Revolution results from this untenable conflict between institutions and nature. In essence, revolutionary violence emerges when political and moral systems have become so distant from our natural inclinations that they cannot be remedied without painful breaks. Revolution is not a return to nature, but a return to a society where natural inclinations are appropriately tailored for a people's context.

As we have mentioned, Diderot often adds the moral dimension to his treatment of war. One of his contributions to the last book of the HDI is a contrast of two visions of war. The first is that one day war will be forgotten, rejected by all for its odious results (19:135). The second is that kings have no conscience, and pursue war at the great expense of their subjects and only for glory (19:136). At another point, he contrasts the moral effects of ancient versus modern war, to the detriment of the latter (19:148-149). Nature may be what leads us to war, but it can and should still be evaluated by moral standards.

\section{War in the colonial context: additional moral factors}

Colonialism has added a new, severe twist to this story as a result of three factors: the clash of European laws and moeurs with the climate and social context of colonized lands; the distance that separates European travelers from the socialized politesse of their homelands; and the character of the Europeans who choose to go abroad. Different continents are a natural limit of power (13:113). But here the problem is not only distance and fossilized laws and

${ }^{21}$ See Whitney Mannies, "Denis Diderot and the Politics of Materialist Skepticism" [in John Christian Laursen and Gianni Paganini, eds.: Skepticism and Political Thought in the Seventeenth and Eighteenth Centuries, Toronto, University of Toronto Press, 2014]. 
structures that try to stand against nature, but also that moral factors cause trouble.

First, less "civilized" societies are less likely to have experienced the distorting factionalism resulting from increased social complexity, so their laws and moeurs are thereby more likely to accord with natural law and the general good. Left alone, they would perhaps endure many generations before their societies contrast so untenably with nature and reason. European colonization, however, has suddenly imposed itself, and in one fell swoop indigenous people have suffered from a double imposition: the conflict of European laws and mours with reason and nature is compounded with their being applied in a wholly inappropriate climate and social context. Europeans may, after all, have some laws and mœurs that are appropriate for them, and for better or worse, they may be inured to those that are not. Where laws are so ill-adapted to the complicated situations they wish to govern, discontent is likely (8:165-166).

Second, distance has unmoored European explorers and colonizers from their social bearings, resulting in an unbridled psychology of domination. In the HDI he writes,

In distancing themselves from their homeland, they are no longer restrained by the fear of blushing before the eyes of their fellow citizens. In a hot climate, where the body loses its vigor, the soul must lose its strength. In a country where nature and customs lead to indolence, they are led astray. In the countries where they come to enrich themselves, they easily forget to be just (3:67-68).

And later:

Beyond the Equator a man is neither English, Dutch, French, Spanish, nor Portuguese. He retains only those principles and prejudices of his native country which justify or excuse his conduct... He is a domestic tiger returning to the forest; the thirst for blood takes hold of him once more $(9: 233-235 ; 178)$.

Nowhere is this more obvious than in the hypocrisy of the English who are so dedicated to liberty at home yet so unrestrained abroad (HDI, 18:286-287; 178). Without the moral ties that limit our cruelty and domination at home, we become inhumane (HDI, 8:196). Distance, both physical and cultural, makes it nearly impossible for any magistrate to be wise enough to govern a colony well (10:53-54). It is very strange that Europe should be transplanted to America, and it will occur sooner or later that the climate will reassert its influence over unsuitable laws that are unable to resist the movement of nature $(9: 237)$. Sankar Muthu (2003) notes that this is the basis of Diderot's argument against colonialism: no distant territory is likely to be justly ruled by a foreigner who is unfamiliar with the local context. What is more, he argues, Diderot's sparse natural law means that "no universally valid, privileged political ideology 
exists that could guide a would-be conqueror" (79-80). As John Pocock puts it, Diderot seems to ask "whether navigation... may not have something in it contrary to human nature"22.

Third, Diderot characterizes those who would leave their home to explore the world as particularly likely to be unscrupulous. He wonders at the motivations that drew the "freebooters" to want to explore and conquer other lands. Those who are detached from their homes are more likely to commit violence and atrocities because they do not feel the strings of mutual affection and sociability that bind them to their fellow men, nor are they sensible to the socialized limits that constrain us in our most domineering behavior. These ruffians deserve the abhorrence with which we often think of them, since their instances of virtue did not impede the atrocities they witnessed or perpetuated (HDI, 10:111-114). Traveling is likely an immoral occupation, since the traveler spurns his home for another, driven on by guilt, ambition, and tyranny. In pre-civilised times, hospitality provided travelers room and board, and this was considered a sacred debt to be preserved and repaid perhaps centuries later. Such exchanges occur less and less as travelers become more rapacious, and traditional relations of hospitality are replaced with financial relationships (9:246-248). Diderot reflects on the motivations that would lead one to become a missionary: religious fervor? Concern for humankind? Not likely. Really, it is the desire of being treated as a god, king, or beloved father among humans one views as lesser - a very base motivation indeed (9:80-81). The special moral depravity attending colonialism disconnects government from nature and the common good in an exceptionally severe way.

There is, however, a far more direct justification of the war of the colonized against their colonizers, and that is the law of nations, which justifies a sovereign people's self-defense. The colonizer is due no more consideration than would a foreign invader, for "Conquérir ou spolier avec violence, c'est la même chose. Le spoliateur et l'homme violent sont toujours odieux" (4: 249). Scholars sometimes characterize Diderot's appeals for colonized peoples to revolt as calls for revolution, but this is not right. When one considers that he was merely exhorting sovereign people to protect themselves from foreign invaders, his appeals are remarkable not for being so radical, but for being so thoroughly conventional. What is radical, however, is the equation of European commerce with injustice and coercion. When doing business with an inhabited country, Europeans who abrogate those people's liberty or property can be justly expelled or killed (8:105-108). Thus Diderot does not hesitate to call on colonized peoples to resist. His speech to the Hottentots is particularly rhetorical: the Europeans, "ravira l'innocence et la liberté. Ou, si vous vous

22 J. G. A. Pocock, Barbarism and Religion. Volume 4: Barbarians, Savages and Empires, Cambridge, Cambridge University Press, 2005, p. 255.

Araucaria. Revista Iberoamericana de Filosofia, Política y Humanidades, año 16, no 32. Segundo semestre de 2014. Pp. 155-171. ISSN 1575-6823 e-ISSN 2340-2199 doi: 10.12795/araucaria.2014.i32.08 
en sentez le courage, prenez vos haches, tendez vos arcs, faite plevoir sur ces étrangers vos fleches empoisonnées. Puisse-t-il n'en rester aucun pour porter à leurs concitoyens la nouvelle de leur desastre!" (2:240). These exhortations are spread across the globe, whether it be in Africa (the Hottentots), Asia (India), Oceana (the Tahitians), South America, or North America ${ }^{23}$.

Note that it is not the case that all commerce is bad. One scholar has noted that Diderot seems to "reveal a generalized ambivalence about luxury - it was often both loved and hated simultaneously", and that in discussing colonial commerce he "argued both sides in a posture best understood as ambivalent" 24 . But this is not quite right, either. As Terjanian also notes, commerce has done some great things such as ending slavery (it was not Christianity that ended it, he insists), and it is also "an essentially civilizing, liberalizing, and pacifying agent" $(83,87)$. But it has also caused great problems: at the core of the issue of monopoly, for example, for Diderot "were the moral problems" it caused (153). Commercial wars are against nature, Diderot writes, but he also observes that they are frequent (HDI, 19:186). So it is not ambivalence, but rather that sometimes commerce has good results and sometimes it has bad results, which seems hard to deny. If one is consistently liberal, one will only support commerce when it has those good effects, and one will criticize it when it has bad effects. And that seems to describe Diderot.

\section{The morality of war in the European context}

But if the clash of social and political institutions with reason and nature is starker for colonized peoples for the reasons mentioned above, this does not mean that Europe lacks such clashes. "Benevolent despotism", which Diderot clearly opposes, is subversive of natural law because, despite whatever justice and enlightenment a tyrant may demonstrate, and even despite the fact that his or her actions may work in the short term toward the people's advantage, benevolent despotism inherently deprives men of their liberty, undermining the very basis of their humanity ${ }^{25}$. And unfortunately, despotism - benevolent and otherwisepervades Europe as elsewhere:

Il n'est que trop vrai: la plupart des nations sont dans les fers. La multitude est généralement sacrifiée aux passions de quelques oppresseurs privilégiés...le citoyen, dépouillé du produit de son travail par les besoins sans cesse renaissans d'un gouvernement avide ou obéré, est continuellement gêné sur les moyens les plus légitimes d'arriver au bonheur (HDI, 11:283).

\footnotetext{
${ }^{23}$ Diderot is clearly in favor of the American Revolution. See HDI (18:273-279).

24 Anoush F. Terjanian, Commerce and Its Discontents in Eighteenth-Century Political Thought, Cambridge, Cambridge University Press, 2013, pp. 67, 152.

25 See Diderot's article “Autorité politique” (DPV, 537-545; p. 207 in Mason and Wokler). Also see HDI (19:39-42).
} 
Still, Diderot makes it clear that the European situation is not quite so desperate as the colonial one, whose abominable condition "n'est pas la même que la nôtre" and which calls for immediate amelioration (HDI, 11:283).

One leitmotif in Diderot's writings on colonialism is the warnings, often highly rhetorical, that he gives to European monarchs, foretelling violent and humiliating punishment for their inhumane behavior:

\begin{abstract}
Vous ne pensez pas qu'on n'avilit point un peuple sans de fâcheuses conséquences. Son honneur peut s'endormir pendant quelque tems: mais tôt our tard il se réveille et se venge; et comme de toute les injures l'humiliation est la plus offensante, c'est aussi la plus vivement sentie et la plus cruellement vengée ${ }^{26}$.
\end{abstract}

But why waste words trying to convince tormentors to give up their tormenting? In fact nature speaks more strongly to those who are oppressed, and slaves will, in time, rise up if they have someone to lead them. Then no European power will be spared.

He also frequently warns European monarchs and merchants that, if they persist in their inhuman policies, they will most certainly be the object of a violent and humiliating revolution abroad ${ }^{27}$. And while Raynal's Histoire des deux Indes may single out Spain as the most ruthless ${ }^{28}$, all European colonial powers are the recipients of frequent invectives. Great Britain, which Diderot greatly admires as a beacon of liberty and constitutional government, is singled out for its hypocrisy. He characterizes the English attack on the Dutch without a declaration of war as savage and uncivilized (17:113). And perhaps most remarkably, he calls for French naval rearmament in order to reverse the British gains of 1763 (Pocock, 293). The HDI can be understood as "a document of state, a programme to enlist Enlightenment in the cause of a French recovery from the disasters of 1763" (Pocock, 323; cf. 325).

Yet while Diderot often predicts revolution, he never actually recommends it to European subjects. While he clearly thinks that Catherine II is a despot, political change in Russia ought to be accomplished through education, or even the strategic introduction of Swiss settlers (ON, 351; IV; 86)! Diderot stops short of recommending war in the European context because he seems to think it far more likely that war will result not in liberty, but in more factionalism. Diderot describes two kinds of war: a war of faction, in which certain groups seek ascendancy over others, and wars of liberty, where citizens fight (violently

\footnotetext{
${ }^{26} \mathrm{HDI}(5: 275)$. Also see (8:232 and 11:275).

${ }^{27}$ See HDI, 4:249-254; 18:292-293; 11:200-201; 7:284-285; 8:118-119.

${ }_{28}$ Maria Jose Villaverde, La Conquista y colonización de la América española, según la Historia de las dos Indias del abate Raynal [in Francisco Castilla, ed., Discursos de conquista y colonización: qué pasó al sur y al norte de América, Alcalá de Henares, Publicaciones de la Universidad de Alcalá de Henares, 2014].
} 
or otherwise) to dismantle noxious factions and restore a reasonable social order in accordance with nature ${ }^{29}$. During civil wars people are divided into factions, each looking to its own interest, and people destroy each other without reason: "Les intérêts particuliers et les haines personnelles font durer les troubles publics; et l'on ne commence à s'expliquer que quand on est las de carnage" (HDI, 7:317). The outcomes of civil war are no better-and are often worse - when war is motivated by the desire to tyrannize in place of the tyrant: "But when the dissensions have an impure source, when slaves fight among themselves to choose a tyrant, or ambitious men fight to oppress, or criminals to share out spoils, the peace which ends such horrors is scarcely preferable to the war that gave birth to them..." $(7: 321 ; 174)$.

Government is such a "very complicated machine" that premature revolution threatens to bring anarchy, not a renewal of liberty ${ }^{30}$. Impatient subjects throw off the oppression of their sovereign, but, lacking a spirit of liberty, they begin to devour each other, or what is equally dangerous, dissolve into a defenseless anarchy. Foreign invaders take advantage of the weakness, and the people may ultimately be worse off than they were before (1:171-172; 170-171).

On the other hand, revolt can have positive consequences when it is motivated by liberty: "When the horrors of tyranny and the instinct of liberty put weapons into the hands of bold men, and they are victorious, then the calm which follows this temporary calamity is a time of the greatest happiness" $(7: 321 ; 174)$. The true citizen described in the article "Citoyen" genuinely looks past his own self-interest in order to support the order and stability of the city, and when factions loom he will embrace whichever party supports "the equality of its members and the liberty of all" (467; Mason and Wokler, p. 16). Often repeated, liberty and equality are the keys to Diderot's politics in the History of the Two Indies. The unique principle of prosperity is liberty (12:48), since liberty to think and to write and to govern oneself lead to prosperity $(13: 302,307)$. English freedom is the best government for the human spirit (14:2). Similarly, the French prosper if they are left free (13:220). An "instinct for independence" drives all peoples (17:26).

But how might wars of faction be avoided and wars of liberty encouraged? This is a matter of cultivating the sentiments of liberty, which include the ability to detach oneself from one's particular self-interest, to be aware of human nature, and to consider the common good (10:120-122). These consequences

29 The dismantling of factions need not be violent. Diderot recommends, with revolutionary rhetoric, "When you have sovereign authority and have to build a new, you must cleanse the air of all such rubbish" (ON, 380; XLIV; 107), but "all such rubbish" refers to "the distinction of conditions and possessions" of the different social classes in a monarchy (379; XLIII; 106). The abolition of unequal privileges and inequality before the law may or may not entail violence.

${ }^{30}$ Diderot uses this phrase in HDI $(1: 171 ; 170)$ and also in $(19: 115 ; 209)$. 
can only result, however, where there is freedom of expression, since it is only in the light of the vigorous circulation of ideas that the common good is illuminated.

In addition, freedom of expression secures philosophers' posthumous influence on the common good. Influence on posterity is the only kind of immortality Diderot aspires to, but he also has a less self-interested reason for encouraging debate from the grave: he envisions the work of liberty as a generations-long struggle, not likely to be completed in one lifetime, and requiring the participation of many liberal thinkers. As Benot notes, posterity is political for Diderot, and freedom of the press is necessary so that the struggle of the philosophes against tyrants and priests may not be in vain (142). Diderot distrusts the masses because their opinions are dictated by priests, yet he also recognizes their importance for any successful revolution (154). Freedom of expression cultivates sentiments of liberty, and only when freedom of expression is allowed to endure can the sentiment of liberty grow sufficiently general, successfully attenuating the grip of superstition on the masses.

The cumulative character of the spirit of liberty is important to note because sometimes Diderot is read as if he referred to the French Revolution. But when Diderot spoke of revolution or wars of liberty, his archetype was of course not the French Revolution (which began five years after his death) but more likely the steady, sometimes violent, but above all generations-long struggle of the British for liberty ${ }^{31}$. In Diderot's view, revolutions were indeed bloody, but they were also collective and long-term projects. "A nation is only regenerated in a bath of blood", he writes, adding, "That seems to be achieved by a long sequence of revolutions. The man of genius passes too quickly and leaves no posterity" (11:170; 184). Convulsive coup d'états do indeed occur (19:115), but Diderot seems not to equate these with revolution. Real, lasting change can only be the outcome of continuous generations of people who cultivate the spirit of liberty $(19: 115)$. Paradoxically, this requires that they have some freedom of expression first.

Freedom of expression can alternately avoid war and bring it about. It can forestall war since freedom of expression allows people to effectively discern the common good and to practically implement it. The best way to assure freedom and equality is the rule of public opinion. Public opinion is the queen of the world, and it brings to light the "permanent interests, the health, and the utility" of the people (18:243-244). In this way, freedom of expression might make war moot. On the other hand, freedom of expression also nurtures the

\footnotetext{
${ }^{31}$ Diderot's view of British history rejected the Gothic interpretation of British liberty as having been rooted in ancient Germanic traditions and embraced the more radical Humean narrative wherein Parliament heroically, if gradually, acquires liberty piecemeal from posturing monarchs. For more on Diderot's view of British history, see J. H. M. Salmon, "Liberty by Degrees: Raynal and Diderot on The British Constitution", History of Political Thought, 20:1 (1999), pp. 87-106.
} 
sentiments necessary for a war of liberty. After all, when people realize their shared interests, they are motivated to wage war for the common good and not merely themselves. Hence freedom of expression alternately contributes to avoiding revolution or to waging the right kind of revolution: Where the free circulation of ideas informs a society's institutions, we should not expect war. Where there is no freedom of expression and institutions operate contrary to nature and the common good, we can expect a war of faction. In those rare instances where freedom of expression exists yet inflexible institutions continue to operate contrary to nature and the common good, we can expect a war of liberty. This was arguably the case in the American colonies.

Indeed, the desire for liberty is so strong that no people will consent to remain oppressed forever. Eventually, they will succeed in overcoming absolutism. Diderot argues that, "all arbitrary power rushes towards its own destruction, and that everywhere revolutions - quicker or slower, sooner or later-bring back the reign of liberty" $(7: 108 ; 174)$. This story-of nature, faction, despotism, and freedom-will re-enact itself in due course in the history of all peoples:

All [countries] follow, more or less often, a regular circle of prosperity and misfortune, liberty and slavery, morality and corruption, enlightenment and ignorance, greatness and weakness; all pass through every point of this fatal horizon. The law of nature, which wills that every society should gravitate towards despotism and dissolution, that empires should be born and die, will not be suspended for any exception $(19: 39-42 ; 207)$.

There are two things to note here. First, Diderot's statement about the "law of nature" suggests a materialist determinism, but the preceding sentence suggests that it is not nature itself that is propelling history through certain stages, but rather society's morality (or lack thereof). Moral factors trump natural factors in the evaluation of war and peace. The morality of nations always ought to be based on the principle that "le bonheur public est la première loi" (18:280). But the context is that all power tends toward despotism (18:277), those who govern are accustomed to contempt for the people (18:260), and where society is almost always good, government is often bad (18:274).

Second, as inevitable as the dissolution of immoral power may be, its end is not predictable. He writes of revolution, "It is a chaos whose end is hard to predict, which only clears after several centuries, and traces of which are never entirely erased, even by the happiest events" $(1: 172 ; 170)$. While it is certain that power contrary to nature will eventually be destroyed, nature, in its infinite complexity, does not suggest a predictable timeline.

At this point it should be clear that Diderot was by no means a pure naturalist and materialist. One of the most striking things about Diderot's contributions 
to the HDI is the moralism that he adds to a text which is otherwise often not particularly concerned with larger moral-philosophical issues. So, for example, in Book 12, what he adds to the discussion of the Spanish conquest of America is the reflection that the conquest should not bring any glory to the Spaniards if the conquest was not a benefit to the Americans (12:1-3). Right after that, when the use of poisoned arrows by the natives of Puerto Rico is discussed, Diderot adds an impassioned attack on the law of nations that the Spaniards claim has been violated, calling it injustice within injustice, observing that the only reason the Spaniards outlaw poisoned weapons is that they have firearms and cannons (12:9).

It is also worth pointing out that when Diderot defends the Puerto Ricans from virtual slavery to the Spaniards, he is not advocating returning to the natural state before the arrival of the Spaniards, but argues in favor of freetrade economic development of the island (12:16). Why won't this happen? Because of the detestable vanity of the Spaniards and their ridiculous puerility (12:17). This is not a materialist, interest-driven explanation, but an attribution of causation to human pride.

Perhaps to capture the agreement of people who might not be sympathetic to beggars, Diderot begins his discussion of endowed hospitals/workhouses in Puerto Rico by condemning many beggars as lazy and thieves, and encourages their incarceration and forced labor (12:29). But then he goes on to explain that this does not apply to the old, the sick, the unemployed soldier or sailor, and by the time he is finished only a small number of beggars fall under the initial condemnation (12:30). And he adds that the hospitals/workhouses designed to help the poor are in fact the sources of many vices. Among others, the administrators tend to divert most of the funds to their own benefit (12:31). By the time this discussion is finished, moral opprobrium has been transferred from beggars to the officials charged with disciplining them.

Diderot can sometimes sound like a Pollyanna: "Injustice was never the foundation of any society" (18:126) - by this he must mean that no society worthy of the name was so founded, or that no society ever admitted to that as a foundation. He argues that virtue is fruitful (18:127), and perhaps he also means that is true at least in the long run, since obvious vice undermines any people or government. His advice to the Americans is all moral: fear wealth, which brings corruption and inequality and the spirit of conquest (18:26). And public education is the key to public morality (18:26).

Governments are rarely fully moral, and that leads them to policies that provoke violence. The English conquest of Canada might have led to future prosperity if the English had not done so much to humiliate the French inhabitants, which will surely mean more violence in the future (17:69). Their envy, zero-sum thinking, and provocation of international animosities in their 
treatment of the Acadians can only have bad consequences (17:81-82). So some wars are quite justified. Thus, Diderot can endorse Thomas Paine's Common Sense (18:298-304) and both defend the English colonists' armed rebellion while arguing against the English case for putting down the rebellion. This war is justified on one side, and not on the other.

A number of scholars have remarked on the ambivalence or contradictions of Diderot's political writings. It is true that he expresses many opinions, under cover of articulating many voices. But that can be understood as a deliberate strategy. John Pocock has drawn attention to a kind of paradox in his writing. Diderot is at once a supporter and a critic of European civilization: "the most arrogant of civilizations is at the same time the most radically given to criticism of itself", and thus a forerunner of "the censorious and resentful world that we ourselves inhabit" (Pocock, 238-239). He observes that "the history which European philosophers told of their civilization was at least as self-contradictory as it was self-congratulatory" (Pocock, 247). And it was precisely this "European self-hatred" and "disputatious culture" that created freedom (Pocock, 247). The paradox is that if the so-called Enlightenment actually succeeded in finding all the truths, there would be no room for intellectual freedom. As Pocock puts it, only by not having truths and final answers can we have such freedom. The question is whether "the concept or the practice of liberty could have existed without the calamitous late antique and European habit of engaging in dispute over insoluble problems", which is also to ask "whether Enlightened authors were not undermining their own enterprise" when they claimed to find truths (244). Which is precisely why Diderot's consistency in his inability or refusal to arrive at fixed conclusions and stand still makes him out as the real Enlightener.

Nevertheless, we are going to try to tease out an overall consistency of message that preserves the criticism and the freedom. Commerce is good where it benefits everyone, as it is supposed to under the ideal of sharing in the benefits of the increased wealth produced by comparative advantage. Commerce is bad if it is imposed under unfair conditions and with unfair results. War is good if it ends tyranny or despotism, and bad if it diminishes liberty, equality, and prosperity. Peace is good if it cultivates the latter, but bad if it freezes inequalities and oppression. These contrasts could be expanded on at length, but the consistency will always be found in Diderot's insistence on the primacy of the common good, the importance of staying within the wide limits of natural law, evaluating matters such as war and peace in their specific contexts, and bringing to bear moral judgments founded in a wide-ranging knowledge of the history of the human world. 
